\title{
Can fallen trees enhance aboveground biomass estimation? A proposal for the Brazilian Atlantic Forest
}

\author{
Nathan Castro Fonsêca ${ }^{1}$, Isabelle Maria Jacqueline Meunier ${ }^{2}$
}

\& Ana Carolina Borges Lins-e-Silva ${ }^{3}$

1. Programa de Pós-Graduação em Ciências Florestais, Universidade Federal Rural de Pernambuco, CEP: $52171-900$ Recife-PE, Brasil; nathanflorestal@hotmail.com

2. Departamento de Ciência Florestal, Universidade Federal Rural de Pernambuco, CEP: 52171-900 - Recife-PE, Brasil; imjmeunier@gmail.com

3. Departamento de Biologia, Universidade Federal Rural de Pernambuco, CEP: 52171-900 - Recife-PE, Brasil; acblsilva@gmail.com

$$
\text { Received 01-IV-2020. Corrected 06-VIII-2020. Accepted 07-IX-2020. }
$$

\begin{abstract}
Introduction: Estimating aboveground biomass (AGB) in protected forests is a challenge, due to high costs and legal restrictions for direct assessments, and also to frequently weak estimation provided by general AGB equations. Objective: We propose a new approach that uses dead fallen trees (DFTs) to improve AGB estimation. We aim to analyse if the adjustment of allometric models based on DFTs provides a suitable local equation for AGB estimation or helps to validate existing pantropical or regional allometric equations. Methods: The study was carried out at the Dois Irmãos State Park (PEDI), Pernambuco, Northeast Brazil. Along $4000 \mathrm{~m}$, using the line intersect technique, we sampled 37 recent dead fallen trees ranging from 7.6 to $92.3 \mathrm{~cm}$ in diameter and from 8.6 to $29.4 \mathrm{~m}$ in height. Nine models were adjusted, and the best equation (local) was compared to regional and pantropical equations. Results: One equation $\left(\mathrm{AGB}_{\mathrm{kg}}=1.5292 * \mathrm{DBH}^{2.0601} * \mathrm{TH}^{-0.2187}\right)$ produced biomass estimates which did not differ from the observed values $(\mathrm{P}>0.05)$. Differently from the others, this equation overestimated AGB in only $2.8 \%$ and, along with other parameters of analysis $\left(\mathrm{R}^{2}\right.$ adj and Syx \%) had the best overall performance. Analysing the performance of the local equation versus available equations for estimating AGB, we found that only the local and the pantropical equations by Pearson et al. (2005) estimated values that were not significantly different from observed values. However, the local equation is more appropriate for local estimation of AGB, since it has the lowest RSME and CV. Conclusions: Based on the proposed approach, we were able to offer a local equation for tree AGB estimation based on fallen trees. The DFT method is efficient regarding time and costs, avoiding tree logging in protected forests and helps to guide the choice of a proper equation for forest AGB demands.
\end{abstract}

Key words: rainforest; allometric equations; dead fallen trees; bole volume; diameter; height; wood density.

Castro Fonsêca, N., Jacqueline Meunier, I.M., \& Borges Lins-e-Silva, A.C. (2020). Can fallen trees enhance aboveground biomass estimation? A proposal for the Brazilian Atlantic Forest. Revista de Biología Tropical, 68(4), 1284-1297.

Atlantic forests biodiversity and ecosystem services are under severe threats. Aboveground biomass (AGB) and carbon storage in these forests play a crucial role in climate regulation. For proper estimation of such compartment, however, allometric equations are required. The absence of specific equations for the Atlantic Forest push researches to use models from other biomes or multibiome (pantropical), which are not designed for meso-or local-scale 
estimates. Therefore, when available, local models must always be employed instead of pantropical models.

Equations for AGB quantification in natural and threatened forests are usually challenging to obtain, because of the costs involved in logging and processing tree samples. Moreover, biomass stocks per area fluctuate with many variables, such as climate type, disturbance history and stand age (AndersonTeixeira, Wang, Garvey, \& Bauer, 2016). Many efforts have been made, over the last decades, for obtaining equations from a variety of tropical forest areas (Chave et al., 2005; Pearson, Walker, \& Brown, 2005; Chave et al., 2014), which can allow proper biomass estimation, especially when a direct quantification is not possible. As a result, many equations have been proposed for biomass estimates from all tropical forests (Pearson et al., 2005; Chave et al., 2014). In the Brazilian Amazon, the largest global forested area, with the most considerable biomass stock and carbon pool (Saatchi et al., 2011), several local and regional equations were also proposed (Vieira et al., 2008). AGB estimations per hectare, however, widely vary; for instance, from $291 \mathrm{Mg} \cdot \mathrm{ha}^{-1}$ to 495 $\mathrm{Mg} \cdot \mathrm{ha}^{-1}$ using the same database and applying different equations to primary Amazonian forests (Alves et al., 1997).

The Brazilian Atlantic Forest is a conservation hotspot, i.e. contains at least 1500 species of vascular plants as endemics ( $>0.5 \%$ of the world's total) and has lost more than $70 \%$ of its original native habitat (Mittermeier, Turner, Larsen, Brooks, \& Gascon, 2011). In this area, the majority of fragments were reduced to less than 50 ha, and almost half the remaining forest is located at less than $100 \mathrm{~m}$ from forest edges (Ribeiro, Metzger, Martensen, Ponzoni, \& Hirota, 2009). Under drastic edge and area effects and facing homogenization and biodiversity erosion (Santos et al., 2008; Lôbo, Leão, Melo, Santos, \& Tabarelli, 2011), large tree densities are commonly reduced in these fragments. In a post-fragmentation condition, the capacity of carbon sequestration and stock is considerably reduced, due to the loss of large and emergent trees, caused by elevated tree mortality near edges, selective wood harvest or by retrogressive succession or forest degeneration (Paula, Costa, \& Tabarelli, 2011).

Nevertheless, such circumstances characterize the main terrestrial carbon sink pool available along the South American coast. Estimations of the biomass and carbon terrestrial pool must consider this new scenario if reliable figures from allometric equations are expected. Few studies have addressed this issue, and those have been based on direct measurements of tree biomass after logging and development of local equations in the Southeastern part of the biome (Tiepolo, Calmon, \& Feretti, 2002; Burger \& Delitti, 2008; Vieira et al., 2008). The absence of a general and suitable equation for biomass estimation in the Atlantic Forest is attributable to several causes: the considerable vegetation heterogeneity within the Atlantic domain, the existence of many secondary areas at different successional stages and under several disturbance regimes and, also because logging is often forbidden, due to technical reasons and protection measures (Vieira et al., 2008). However, research on AGB estimation ought to address this question and advance on proposing a reliable assessment of tree AGB for a consistent quantification of the carbon stocked in these forests.

In the absence of alternative methods for assessing biomass or testing existing equations, general equations for tropical and Amazonian forests are often applied to obtain AGB estimates in Atlantic Forests (Paula et al., 2011). Application of existing equations, however, may generate poor figures and, consequently, over- or under-estimate carbon stocks (Huy, Poudel, \& Temesgen, 2016). Therefore, there is a demand for the development of specific equations (Ngomanda et al., 2014) that considers logging restrictions, or at least to develop a way of testing if existing equations are suitable for estimating AGB from different forest remnants in the Atlantic Forest.

An alternative for the development of a biomass assessment in such situation is using recent dead fallen trees (DFTs) for rigorous 
measurement of tree volumes and densities in a specific area. Although this approach has been frequently applied for necromass estimation, the assessment of live AGB based on the methods, equations and stocks of fallen or standing dead trees have been little explored. In Brazil, studies on necromass were predominantly conducted in the Amazon rainforest (Chambers, Higuchi, Schimel, Ferreira, \& Melack, 2000; Keller, Palace, Asner, Pereira, \& Silva, 2004; Baker et al., 2007; Palace, Keller, \& Silva, 2008; Chao, Phillips, \& Baker, 2008; Chao et al., 2009; Silva et al., 2016; Barbosa et al., 2019). In the Atlantic Forest, studies on necromass are in their initial stages. Particularly on the thick necromass compartments (CWD and SDT), there are even fewer studies (Sanquetta, Corte, Pinto, \& Melo, 2014; Deus, Bonete, Figueiredo, Dias, \& Bonete, 2018; Moreira, Gregoire, \& Do Couto, 2019; Fonsêca, Meunier, \& Silva, 2019; Villanova et al., 2019).

Considering the scarcity of studies on AGB for the Northeastern Atlantic forest, our research aims at proposing a new approach for improving tree AGB estimation, the DFT approach. Our primary research question is if the adjustment of allometric models based on DFTs provides a suitable local equation for AGB estimation and helps to validate existing pantropical or regional allometric equations for tropical forests.

This approach appears advantageous for three reasons: 1) sounds efficient regarding time and costs, 2) avoids tree logging in protected forest remnants, and 3) allows assessing the estimation power of general equations for AGB estimates. We based our proposal on the assumption that wood density in recent DFTs (up to three months after falling, no signs of attack by insects or fungi, nonexistent or imperceptible decomposition, and still bearing leaves) is significantly related to the density of live trees in the same site (Chao, Phillips, \& Baker, 2008). This way, we accept the application of DFTs to enhance the estimation of standing biomass in forests under restrictive protection.

\section{MATERIALS AND METHODS}

Study area: The study was carried out in a remnant of Atlantic Forest (lowland dense moist forest), located at the Dois Irmãos State Park, a protected area in the State of Pernam-

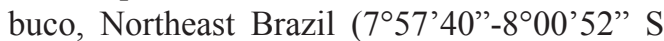
\& $34^{\circ} 56^{\prime} 23^{\prime \prime}-34^{\circ} 57^{\prime} 31^{\prime \prime} \mathrm{W}$ ), within a periurban matrix and under the negative impacts of matrix changes over the last years. The forest covers 1 158 ha, of which 384 ha are mature forest, and 774 ha are young regenerating forest. Climate is coastal tropical wet and hot, classified as As' in the Köppen-Geiger system. Mean annual precipitation amounts to $2417 \mathrm{~mm}$ with a maximum in autumn-winter, whereas mean monthly temperatures are always above $23{ }^{\circ} \mathrm{C}$ (Data available from the Instituto Nacional de Meteorologia repository: www.inmet.gov.br). Predominant soil types are Latosol, Argisol and Quartzarenic Neosols, following the Brazilian Soil Database (Benedetti, Curi, Sparovek, Carvalho Filho, \& Silva, 2011).

Sample design and methods: The analyzed data included: 1) dead fallen trees (DFTs) sampled using the line intersect technique, described by Warren and Olsen (1964); 2) a forest inventory dataset of the Biodiversity Research Program, Atlantic Forest Network (PPBio-MA), Site PEDI. In this site, a sampling module was set up according to the RAPELD method, which combines rapid assessment surveys, RAP, with long-term ecological research, LTER or PELD in the Portuguese contraction (Magnusson et al., 2005). Out of the trails and permanent plots systematically established, we used as transects $250 \mathrm{~m}$-central lines in the center of four RAPELD plots, plus $3000 \mathrm{~m}$ of trails, adding together $4000 \mathrm{~m}$ sampled (Fig. 1).

Along the $4000 \mathrm{~m}$ line, we sampled trees recent fallen (up to three months), with assorted diameters and heights. All sampled trees exhibited physical integrity, with a base, a complete trunk and no signs of attack by insects or fungi, decomposition nonexistent or imperceptible, and still bearing leaves in most cases. The minimum criterion for sampling a fallen tree 


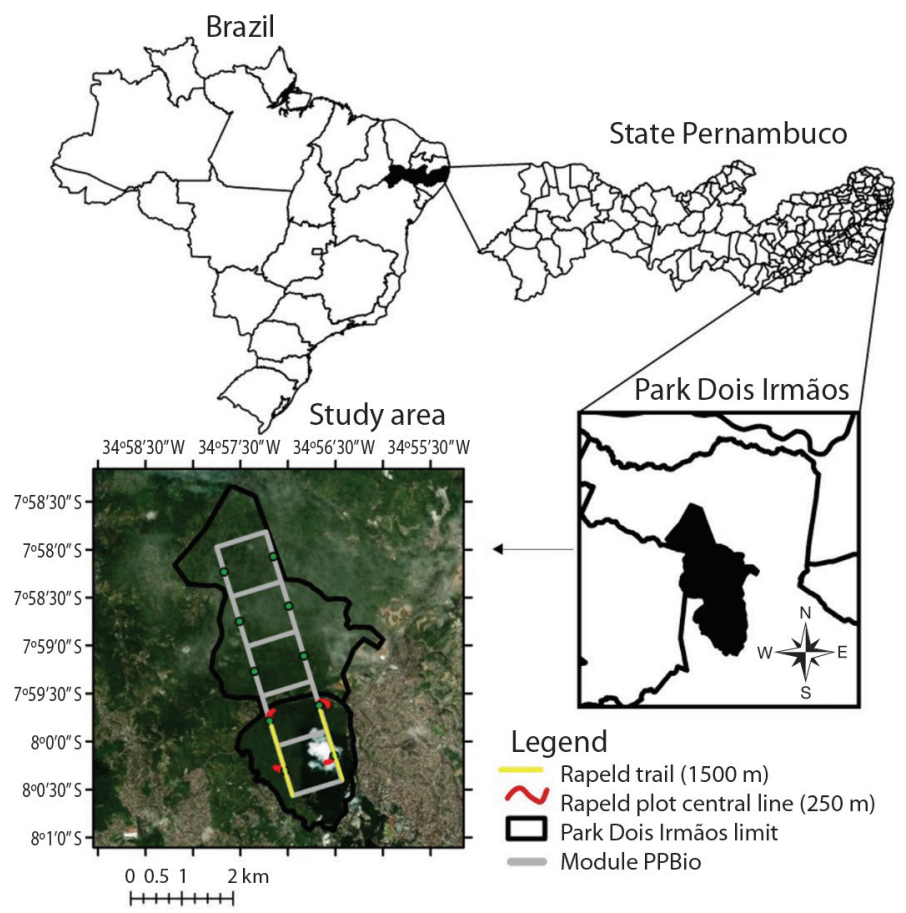

Fig. 1. Study area, Dois Irmãos State Park (PEDI), State Pernambuco, Brazil, with indication (in red) of the line transect used for sampling dead fallen trees for assessment of tree aboveground biomass (AGB) in a RAPELD plots along the PPBio module.

was a diameter at $1.30 \mathrm{~m}$ from stem base (the equivalent $\mathrm{DBH}) \geq 5 \mathrm{~cm}$, measured with a tree caliper. For every tree, we measured DBH, total height (TH) and wood basic density (WBD). WBD was obtained from a sampling disk of $5 \mathrm{~cm}$ taken from the first branch of each tree, which was later estimated by the ratio of kiln-dried mass at $105 \pm 2{ }^{\circ} \mathrm{C}$ by the respective volume of the wood above the fiber saturation point (green volume or saturated volume), according to the standard method (ABNT, 2003; Chave et al., 2009; Zanne et al., 2009). To guarantee that densities of dead trees could be applied in the method, we compared WBD of all dead trees to the WBD of live trees sampled by Monteiro, Lima, Silva, Silva and Rodal (2017) from an adjacent forest fragment, under the same conditions (size, climate and conservation status), using a Student t-test (paired) at $5 \%$ of probability.

The volume of each tree $\left(\mathrm{m}^{3}\right)$ was obtained applying the Smalian equation (Equation 1), which takes into account that the stem of a tree does not correspond to a simple geometric volume, that is, in the form of a cylinder as some equations consider. Based on this, we propose the application of Smalian, by using the transversal areas obtained from sections along the trunk length (at $0.3 ; 0.7 ; 1.3 ; 2.0 \mathrm{~m}$ and at every meter successively, until the total height of the tree), thus reducing the error in the estimate of the volume, and later, of tree biomass. In trees with more than one stem, all of them were included in the volume estimation.

$\boldsymbol{V}_{\boldsymbol{E} s \boldsymbol{t}}=g_{1}+g_{n-1}+2\left(g_{2}+g_{3}+g_{4} \cdots g_{n-2}\right)+\frac{g_{n-1}+g_{n}}{2} \cdot L_{n}$

Where: estimated volume $\left(\mathrm{m}^{3}\right) ; g_{1,2,3,4}$ : crosssectional area $1,2,3,4 ; g_{\mathrm{n}-1}$ : cross-sectional area of the last but one section; $g_{\mathrm{n}-2}$ : crosssectional area of the third-to-last section; $g_{n}$ : cross-sectional area of the last section; $L_{\mathrm{n}}$ : length of the last section.

For each tree, we multiplied the values of $W B D$ and VEst to calculate the individual 
aboveground biomass (AGB). On the top of every calculated value, we added $33 \%$ to account for the crown elements (branches and leaves). The added value is within the expected for crown biomass in dense forests, corroborating data from Da Silva (2007) and Nogueira Junior, Engel, Parrotta, Melo, and Ré, (2009), in which the crown biomass is approximately $31 \%$ of the above-ground biomass of the entire tree or $34 \%$, according to Higuchi et al. (1998). This procedure corrected the estimation, considering that AGB from dead fallen trees was measured only for the trunks and branches ( $>$ $5 \mathrm{~cm}$ diameter). We are aware that an accurate estimation for the biomass of leaves and branches could be obtained through existent technological approaches such as LiDAR and 3D modelling for assessing tropical trees architecture (Lau et al., 2018); however, these methods are expensive and do not match our need of a low-cost approach.

We tested the data for normal distribution applying the Shapiro-Wilk test at $5 \%$ of significance. In the case of a non-normal distribution of the dependent variable ( $D A G B$ $<0.05$ ), data was transformed using BoxCox to determine the correct transformation for the sample records. Based on the results of the Lambda value (0), we chose to perform a logarithmic transformation for data adjustment (Box \& Cox, 1964); afterwards, for comparisons between equations, data were back-transformed to AGB values (kg.tree $\left.{ }^{-1}\right)$. Besides, we used the Pearson correlation $(r)$ between a dependent variable (AGB) and independent variables $(D B H, T H$ and $W B D)$. We adjusted nine mathematical models, deduced through the principle of parsimony (Steel and Penny 2000), i.e., "simplest models" the "more complex" (Table 1), to obtain equations for AGB estimation in this fragment of Atlantic Forest. The models were chosen based on the variables that we had available and also, based on a search in the literature, and appreciating their potentials in estimating and explaining the AGB. Independent variables selected were: $D B H, T H$ and $W B D$, along with their combinations $\left(D B H 2 * T H ; D B H^{*} T H\right.$ and $W B D * D B H 2 * T H)$. These variables are straightforward to measure in the field, with small risks of measurement errors, require fewer workforces for field measurements and involve low costs. Besides, these variables are highly correlated to tree biomass and enable accurate estimations when coupled in the same equation (Chave et al., 2014).

The non-linear models I, II and III (Table 1) were linearized using log transformation (Box \& Cox, 1964). Precision measures of the equations originating from these logarithmic

TABLE 1

Volumetric models adapted to biomass estimation, from the data collected in dead fallen trees (DFTs) in the Dois Irmãos State Park, Recife, State Pernambuco, Brazil

\begin{tabular}{|c|c|c|}
\hline Models & Authorship & Mathematical Formulation \\
\hline (I) & $\operatorname{Husch}(1963)$ & $\operatorname{Ln} A G B_{(k g)}=\beta_{0}+\beta_{1} * \operatorname{Ln}(D B H)+\varepsilon_{i}$ \\
\hline (II) & Spurr (1952) & $\operatorname{Ln} A G B_{(k g)}=\beta_{0}+\beta_{I *} \operatorname{Ln}\left(D B H_{*}^{2} T H\right)+\varepsilon_{i}$ \\
\hline (III) & Schumacher (1942) & $\operatorname{Ln} A G B_{(k g)}=\beta_{0}+\beta_{1 *} \operatorname{Ln}(D B H)+\beta_{2 *} \operatorname{Ln}(T H)+\varepsilon_{i}$ \\
\hline (IV) & Finger (1992) & $A G B_{(k g)}=\beta_{0}+\beta_{I^{*}}\left(D B H^{2}\right)+\varepsilon_{i}$ \\
\hline (V) & Schumacher \& Hall (1933) & $A G B_{(k g)}=\beta_{0} * D B H^{\beta 1}{ }_{*} T H^{\beta 2}+\varepsilon_{i}$ \\
\hline (VI) & Meyer (1944) & $A G B_{(k g)}=\beta_{0}+\beta_{1^{*}}(D B H)+\beta_{2^{*}}\left(D B H^{2}\right)+\beta_{3^{*}}\left(D B H^{*} T H\right)+\beta_{4^{*}}\left(D B H^{2}{ }_{*} T H\right)+\beta_{5^{*}}(T H)+\varepsilon_{i}$ \\
\hline (VII) & Näslund (1940) & $A G B_{(k g)}=\beta_{0}+\beta 1\left(D B H^{2}\right)+\beta_{2^{*}}\left(D B H^{2}\right)_{*}(T H)+\beta_{3^{*}}\left(D B H_{*} T H^{2}\right)+\beta_{4^{*}}\left(T H^{2}\right)+\varepsilon_{i}$ \\
\hline (VIII) & Tiepolo et al., (2002) & $A G B_{(k g)}=\beta_{0}+\beta_{1^{*}}(D B H)+\beta_{2 *}\left(D B H^{2}\right)+\varepsilon_{i}$ \\
\hline (IX) & Chave et al. (2014) & $A G B_{(k g)}=\beta_{0}\left(W B D{ }_{*} D B H^{2}{ }_{*} T H\right)^{\beta 1}+\varepsilon_{i}$ \\
\hline
\end{tabular}

Where AGB: aboveground biomass $\left(\mathrm{kg} \cdot \mathrm{tree}^{-1}\right) ; D B H$ : diameter at breast height $(\mathrm{cm}) ; T H$ : total tree height (m); WBD: wood basic density $\left(\mathrm{g} . \mathrm{cm}^{-3}\right)$; $\beta$ i: model parameter; $L n$ : natural logarithm. 
models were corrected; after such corrections, the comparison with the results of linear equations was acceptable. The Meyer correction factor (Equation 2), was used to mitigate the logarithm discrepancy (Rezende, Vale, Sanquetta, Filho, \& Felfili, 2006).

$$
\boldsymbol{F}_{\boldsymbol{c}}=e^{(0,5 * R S M)}
$$

In which: $\mathrm{F}_{\mathrm{c}}=$ Correction factor for logarithm discrepancy; and $\mathrm{e}=$ exponential; $R S M=$ residual squared mean of the logarithmic equation.

Selection of equation and comparison to regional and pantropical equations. Selection of the best local equation was carried out based on the following statistical criteria: analysis of variance (' $F$ ' test; $\mathrm{P} \leq 0.01$ ); higher adjusted coefficient of determination ( $\left.R^{2} a d j\right)$; smaller standard error of estimate $(S y x \%)$; and graphical analysis of residuals to check out for the occurrence or not of biases in the estimation of the dependent variable (Djomo \& Chimi, 2017).

The chosen local equation was compared to regional equations developed by Burger, and Delitti, (1999) and Burger and Delitti, (2008) and to pantropical equations (Brown, Gillespie, \& Lugo, 1989; Pearson et al., 2005; Chave et al., 2014). The choice of equations (Table 2) took into consideration the diametric amplitude, the precision in the estimates and the possibility of applying them in the study area. The comparison aimed at assessing the performance of each equation in providing AGB (kg.tree ${ }^{-1}$ ) estimation.
For each equation (six in total: five available from the literature and the local equation), the equivalence between observed and estimated AGB values were assessed via analysis of a dispersal diagram, root mean squared error (RMSE), the mean AGB at the site and the coefficient of variation (CV), as described by Chave et al., $(2005,2014)$, and the Student's " $t$ " test (paired) between observed values and estimates to identify significant biases in the estimations (Chave et al., 2005; Fayolle et al., 2013).

$$
\begin{gathered}
\boldsymbol{R S M E}=\sqrt{\frac{1}{n} \sum_{i=1}^{n}\left(A G B_{\text {est }, i}-A G B_{o b s, i}\right)^{2}} \\
\boldsymbol{M A G B}=\frac{1}{n} \sum_{i=1}^{n} A G B_{o b s, i} \\
\boldsymbol{C V}=\frac{R S M E}{M A G B}
\end{gathered}
$$

Where $A G B_{\text {est }, i}$ and $A G B_{\text {obs }, i}$ are the estimated and observed aboveground biomass for a tree $\mathrm{i}$, respectively, and $\mathrm{n}$ is the total number of trees.

Subsequently, the appropriate equation was chosen (t-test not significant, lowest RSME, lowest CV) for AGB estimation in the studied area. For that, we used a local forest inventory dataset accomplished by Aguiar et al. (unpublished data) covering two hectares (two plots of $250 \mathrm{~m} \times 40 \mathrm{~m}$ ), in which all trees with $\mathrm{DBH} \geq 5 \mathrm{~cm}$ were measured (DBH and TH). Software DataFit 8.0.32 (Oakdale Engineering, Oakdale, PA, EUA) was used for adjustment and attainment of model parameters and Software $\mathrm{R}$ version 3.6.3 Corrgram package was used for analyses.

TABLE 2

Allometric equations selected for estimates of above ground biomass in the study area (Dois Irmãos State Park) in the Atlantic Forest, Northeast Brazil

\begin{tabular}{llc}
\multicolumn{1}{c}{ Authorship } & \multicolumn{1}{c}{ Equation Formula } & $R^{2}{ }_{a d j}$ \\
Brown et al., (1989) & $\operatorname{LnAGB}_{(\mathrm{kg})}=-3.1141+0.9719_{*} \operatorname{Ln}\left(D B H^{2}{ }_{*} T H\right)$ & 0.97 \\
Burger \& Delitti (1999) & $\mathrm{AGB}_{(\mathrm{kg})}=-5.714+0.023_{*} D B H^{2}{ }_{*} T H$ & 0.95 \\
Burger \& Delitti (2008) & $\mathrm{LnAGB}_{(\mathrm{kg})}=-4.15190+1.06068 \operatorname{Ln}\left(D B H^{2}{ }_{*} T H\right)$ & 0.81 \\
Chave et al. (2014) & $\mathrm{AGB}_{(\mathrm{kg})}=0.0673_{*}\left(\mathrm{WBD}{ }_{*} D B H^{2}{ }_{*} T H\right)^{0.976}$ & 0.95 \\
Pearson et al. (2005) & $\mathrm{LnAGB}_{(\mathrm{kg})}=-2.289+2.649_{*} \operatorname{Ln}(\mathrm{DBH})-0.021_{*} \operatorname{Ln}(\mathrm{DBH})^{2}$ & 0.96 \\
\hline
\end{tabular}

Where AGB: above ground biomass $\left(\mathrm{kg} \cdot \operatorname{tree}^{-1}\right) ; D B H$ : diameter at breast height $(\mathrm{cm}) ; T H$ : total tree height $(\mathrm{m})$; WBD: wood basic density $\left(\mathrm{g} . \mathrm{cm}^{-3}\right) ; \mathrm{Ln}$ : natural logarithm and $R_{a d j}^{2}$ : adjusted coefficient of determination. 


\section{RESULTS}

A total of 37 recently dead fallen trees (DFT) was sampled (Digital Appendix 4), which covered the amplitude of diameters and heights of the standing live tree (SLT) assemblage in the forest: $D B H$ from 7.6 to $92.3 \mathrm{~cm}$ (34.60 \pm 17.99$)$ in the DFT, $D B H$ from 5 to $114 \mathrm{~cm}(15.65 \pm 13.82)$ in the SLT; heights from 8.6 to $29.4 \mathrm{~m}(18.18 \pm 5.01)$ in the DFT, heights from 2 to $27 \mathrm{~m}(10.73 \pm 5.87)$ in the SLT. Mean $W B D$ for DFTs was $0.6413{\mathrm{~g} . \mathrm{cm}^{-3}}^{-3}$ $( \pm 0.14)$, which did not differ from $W B D$ values of the SLTs sampled by Monteiro et al. (2017) $\left(0.6437 \pm 0.12\right.$ g.cm $\left.{ }^{-3} ; P=0.9371\right)$. DFTs' volume ranged from 0.12 to $10.28 \mathrm{~m}^{3}(2.38 \pm$ 2.37) per individual, whereas individual biomass varied from 64.14 to $7897.4 \mathrm{~kg} \cdot$ tree $^{-1}$ (1 $536.97 \pm 1701.33)$.

We observed a positive correlation between the dependent variables $D B H$ and $T H$, and also between these variables and AGB, while the variable $W B D$ had a low correlation with all other variables (Digital Appendix 1). Nine models were fit and resulted in different parameters $(\beta 0-\beta 2)$ and values of model fit indicators (R2adj and Syx \%) to the estimation of AGB (Table 3).

All equations had high and significant $(\mathrm{P}<$ $0.01)$ values for the adjusted R-squared $\left(R^{2} a d j\right)$, ranging from 0.82 to 0.92 . Best results were obtained for six equations (IV to IX) when compared to the logarithmic equations (I, II e III), the latter group achieving the lowest model fits. Looking at the standard error of estimate in percentage (Syx \%), equations I, II and III had the worst results again, with equations IV to IX exhibiting lowest values.

Based on the graphical analysis of residuals (Digital Appendix 2), we observed that all equations had a similar behavior regarding the variance homogeneity; however, most equations tended to under or overestimate AGB. A detailed analysis of residuals allowed us to detect that the best estimation for AGB was provided by equations generated from the models $\mathrm{V}\left(\mathrm{AGB}_{\mathrm{kg}}=\beta 0 * \mathrm{DBH}^{\beta 1} * \mathrm{TH}^{\beta 2}+\varepsilon \mathrm{i}\right)$ and IX $\left(\mathrm{AGB}_{\mathrm{kg}}=\beta 0\left(\mathrm{WBD}^{*} \mathrm{DBH}^{2 *} \mathrm{TH}\right)^{\beta 1}+\varepsilon \mathrm{i}\right)$.

Differently from the others, equations $\mathrm{V}$ and IX overestimated AGB in only $2.8 \%$ and, along with other parameters of analysis $\left(\mathrm{R}^{2}\right.$ adj and $S y x \%$ ), had the best overall performance. Logarithmic equations I and III underestimated AGB in 18.9 and $10.8 \%$, respectively, whereas equation II overestimated the biomass in 10.8 $\%$. Linear equations IV, VI and VII overestimated AGB by more than $16 \%$, which indicated heteroscedastic behavior. Observed biomass values from DFTs and estimated values by equations $\mathrm{V}$ and IX were not significantly different (t-test, $\mathrm{P}>0.05$, Fig. 2).

TABLE 3

Parameter estimation and model fit indicators from nine models used to estimate aboveground biomass (AGB) from 37 recent dead fallen trees (DFT) in the Atlantic Forest, Dois Irmãos State Park, Northeast Brazil

\begin{tabular}{|c|c|c|c|c|c|c|c|c|}
\hline \multirow{2}{*}{$\begin{array}{l}\text { Models for AGB estimation, in } \\
\text { decrescent order of performance }\end{array}$} & \multicolumn{6}{|c|}{ Parameters (all significant at 0.01 level of significance) } & \multirow{2}{*}{$R_{a d j}^{2}$} & \multirow{2}{*}{$S_{y x}(\%)$} \\
\hline & $\beta_{0}$ & $\beta_{1}$ & $\beta_{2}$ & $\beta_{3}$ & $\beta_{4}$ & $\beta_{5}$ & & \\
\hline Schumacher \& Hall (1933) & 1.529 & 2.060 & -0.218 & - & - & - & 0.92 & 31.27 \\
\hline Chave et al. (2014) & 1.633 & 0.702 & - & - & - & - & 0.92 & 31.43 \\
\hline Finger (1992) & 80.052 & 0.958 & - & - & - & - & 0.91 & 33.56 \\
\hline Näslund (1940) & -584.491 & 1.036 & 0.025 & -0.130 & 4.606 & - & 0.90 & 33.85 \\
\hline Tiepolo et al., (2002) & 116.307 & -1.901 & 0.977 & - & - & - & 0.90 & 34.05 \\
\hline Meyer (1944) & -705.951 & -48.654 & 2.367 & -1.156 & -0.028 & 114.303 & 0.90 & 34.44 \\
\hline Spurr (1952) & -1.480 & 0.852 & - & - & - & - & 0.85 & 44.20 \\
\hline Schumacher (1942) & -1.481 & 1.702 & 0.854 & - & - & - & 0.84 & 44.96 \\
\hline Husch (1963) & -0.169 & 2.034 & - & - & - & - & 0.82 & 36.12 \\
\hline
\end{tabular}

$R_{a d j^{*}}^{2}=$ adjusted coefficient of determination; $S_{y x}(\%)=$ standard error of estimate in percentage; $\beta_{0,}, \beta_{l}, \beta_{n},=$ regression coefficients. 
Equation V

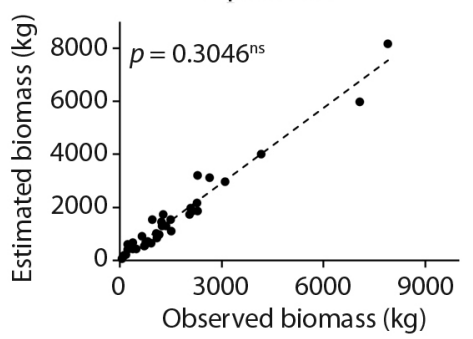

Equation IX

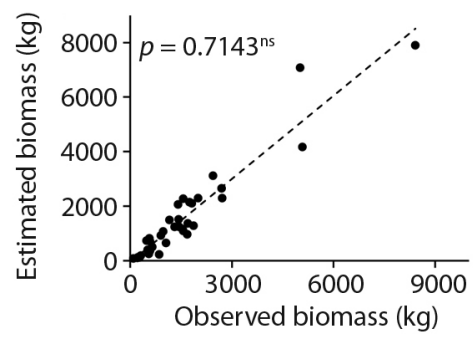

Fig. 2. Dispersal diagram and t test at $5 \%$ of significance, for equations V and IX, generated for estimation of aboveground biomass $\left(\mathrm{kg}_{\mathrm{f}} \mathrm{tree}^{-1}\right)$ from dead fallen trees in the Atlantic Forest, Dois Irmãos State Park, Northeast Brazil.

*significant; ns= non significant.

Amongst the two equations, equation $\mathrm{V}$ $\left(\mathrm{AGB}=1.5292 * \mathrm{DBH}^{2.0601} * \mathrm{TH}^{-0.2187}\right)$ had the best overall result, especially when looking at the graphical analysis of residuals, besides the fact that it includes only the variables $D B H$ and $T H$ as independent variables, whereas the equation IX also uses $W B D$. The variable $W B D$ is much more time-consuming to obtain in the field and was not correlated to AGB in this study.

Performance of local equation versus available equations for estimating tree AGB: The observed biomass for the 37 sampled DFTs summed $56.87 \mathrm{Mg}$. Only two equations estimated values that were not significantly different from observed values $(\mathrm{P}>0.05)$ : local and Pearson et al., (2005) equations (Fig. 3). Local equation estimated $55.84 \mathrm{Mg}$, while Pearson et al. (2005) equation estimated 52.89 $\mathrm{Mg}$. However, the local equation exhibited the lowest RSME and CV. Using available equations, we observed an underestimation of tree biomass in all, including the Pearson et al., (2005), which underestimated the biomass of individuals with smaller diameters (5 to $25 \mathrm{~cm}$ ) (Digital Appendix 3).

Therefore, we decided for the local equation for estimating tree AGB, following the formula: $\mathrm{AGB}=1.5292 * D B H^{2.0601 *} \mathrm{TH}^{-0.2187}$. As a result, the estimated tree AGB was 255.67 $\mathrm{Mg} \cdot \mathrm{ha}^{-1}$ for the studied forest.

\section{DISCUSSION}

Our proposed approach using dead fallen trees (DFTs) proved to be a suitable tool for estimating forest AGB and for evaluating existing equations for such estimations. The method saves time and costs and also avoids direct assessments based on tree logging. When using the same methodology, care should be taken when sampling the fallen trees, always seeking to select those that have physical integrity and the presence of leaves, with a complete base and trunk and without signs of attack by insects or fungi and non-existent or imperceptible decomposition. This care will avoid mistakes, since most fallen trees suffer from diseases and have been infected by fungi and insects (termites, beetles), with hollow trunks (Palace et al., 2007).

Thus, it is a promising approach for enhancing AGB estimations. Based on fallen trees, a common and frequent component in these forests, we were able to generate nine allometric equations and choose one for its best performance. The resulting equation is easy to apply and requires only two variables (DBH and $\mathrm{TH}$ ), which is a desirable characteristic of high-quality equations (Vieira et al., 2008; Huy et al., 2016).

Defining a robust equation of high quality and low cost to AGB estimation in tropical forests is a current and urgent need 
Local Equation
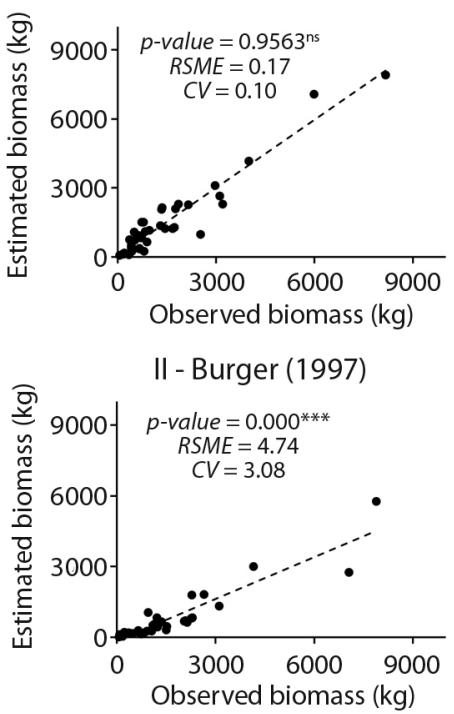

IV - Chave et al. (2014)

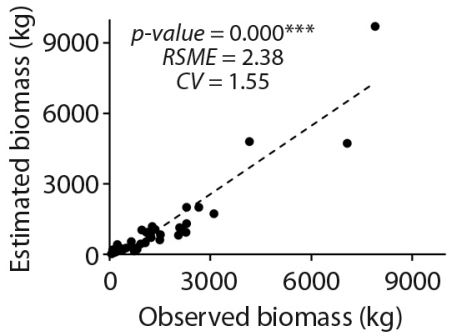

I - Brown et al. (1989)

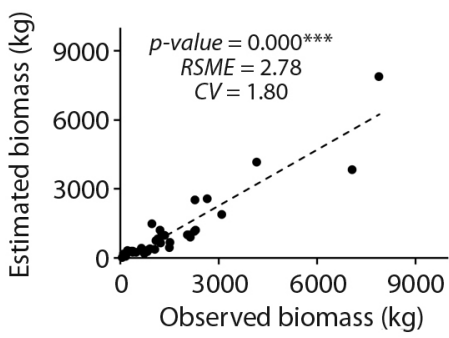

III - Burger (2005)
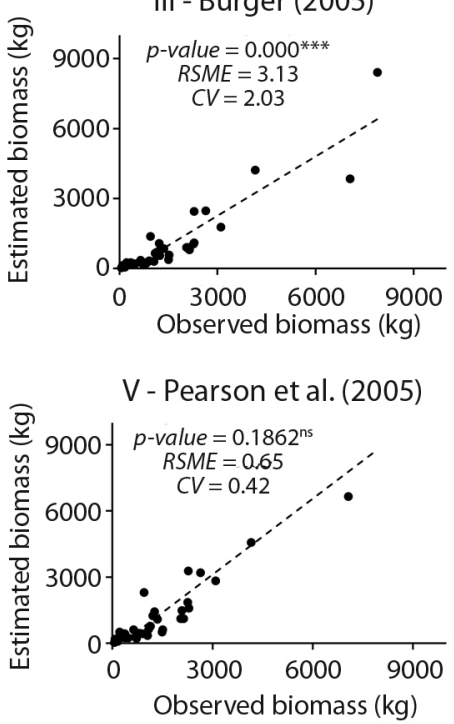

Fig. 3. Dispersal diagram showing observed and estimated aboveground biomass (AGB) for 37 dead fallen trees in the Atlantic Forest, Dois Irmãos State Park, Brazil, applying the local equation and five available equations (I to V).

$P$-values for Student's " $t$ " test (paired), root mean squared error $(R S M E)$, and the coefficient of variation $(C V)$. ***significant; $\mathrm{ns}=$ not significant.

(Chave et al., 2005; Chave et al., 2014). Much research has been carried out with this purpose and pointed out that pantropical equations generate reasonable estimations of tropical forest biomass (Stas, Rutishauser, Chave, Anten, \& Laumonier, 2017), mainly when applied to continental and global scales. These equations, however, were generated based on an extensive database joining information from large and conserved forest patches, with high tree density and large diameters. When such pantropical equations are applied to forest patches where the general structure departs from the expected for pristine forests, there is often a bias on their estimates due to local constraints (Alvarez et al., 2012; Huy et al., 2016).

Studies indicate that such generic equations might lead to systematic errors of up to $400 \%$ at the site level (Alvarez et al., 2012; Chave et al., 2014; Ngomanda et al., 2014). Such errors are usually associated with differences on climate, allometric relations, forest architecture and wood densities (Ketterings, Coe, Noordwijk, Ambagau, \& Palm, 2001), as well as conservation status, mortality rates, edge and size effects. For instance, recent studies aiming at estimating AGB applying general pantropical versus local equations found 
that pantropical models overestimated the AGB in Vietnamese forests (Huy et al., 2016) and Central Africa woods (Ngomanda et al., 2014). Alvarez et al., (2012) applying the pantropical equation by Chaves et al. (2005) in natural forests of Colombia verified AGB overestimation by approximately 300 to $400 \%$ of the two dry forests assessed.

On the contrary, in our study, the equations available from the literature (regional and pantropical) underestimated AGB from the DFT sample up to $33.45 \%$, while the sitespecific equation underestimates in only $6.7 \%$. This result makes most available regional and pantropical equations for AGB inappropriate for estimating biomass in this fragmented and threatened forest, where the average density per hectare is of 842 stems, among which around $88.6 \%$ have $D B H$ between 5 and $25 \mathrm{~cm}$.

Based on the limitations of pantropical equations, one must take into account the scale of the study and the purpose of the research. Concerns raised by Chave et al., (2005) and Chave et al., (2014) demonstrate that pantropical equations will always fail when compared to specific equations, but that in the absence of the local equation, they should always be used. When research on the subject poses the dilemma between using site-specific or pantropical equations, usually it points the solution applying destructive methods, with an effort that may include logging of up to 845 trees (Fayolle et al., 2018). However, this technique requires tremendous financial resources and may also lead to forest degradation. We pointed out a solution to approach this dilemma in situations where destructive methods are not possible or recommended.

Applying our site-specific equation, we recorded $255.67 \mathrm{Mg}$. $\mathrm{ha}^{-1}$, which seems to be compatible to the tree density of 842 ind. ha $^{-1}$ with $D B H \geq 5 \mathrm{~cm}$ and correspond to the intermediate band of the expected range for the Atlantic Forest AGB (Alves et al., 2010). The pantropical equations by Chave et al., (2014) and Pearson et al., (2005) underestimated AGB

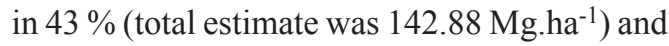
$21 \%$ (200 Mg.ha-1), respectively. In Atlantic
Forest, tree AGB varies as much as from 40 to $350 \mathrm{Mg} \cdot \mathrm{ha}^{-1}$, depending on abiotic conditions - mainly temperature and rainfall (Alves et al., 2010), physiognomy - height, basal area, density (Chave et al., 2005; Nogueira Junior, Engel, Parrotta, Melo, \& Ré, 2014), or disturbance status (Paula et al., 2011). Alves et al., (2010) compiled a list of 25 AGB estimates for Neotropical Forests and reported values varying from 109 to $360.2 \mathrm{Mg}$. ha ${ }^{-1}$. When they focused only on estimates for the Atlantic Forest, applying the pantropical allometric equation by Chave et al. (2005), numbers varied from 154

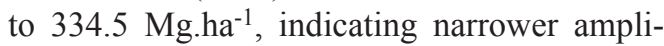
tude. To what extent numbers are influenced by estimation approaches (local versus pantropical equations) is still an unsolved question.

If AGB is explained by climate, anthropogenic disturbance, forest density or sample biases is still a matter of examination. For instance, despite the similar density (830 ind. $\mathrm{ha}^{-1}$ ), the estimated tree AGB reported here is much more substantial than the value reported by Cunha, Gama-Rodrigues, Gama-Rodrigues, \& Velloso (2009), which were 148.41 and 167.86 Mg.ha- ${ }^{-1}$ for Atlantic Forest remnants in the Southeastern Brazil, of smaller sizes (10-200 ha), younger ages (40 years), and under a drier climate. According to Paula et al. (2011), forest fragmentation reduces the ecosystem capacity to retain biomass, due to area and edge effects, leading to storage of only one-third of the AGB recorded from interior forest environments.

Ethical statement: authors declare that they all agree with this publication and made significant contributions; that there is no conflict of interest of any kind; and that we followed all pertinent ethical and legal procedures and requirements. A signed document has been filed in the journal archives.

\section{ACKNOWLEDGMENTS}

This study was supported by the Conselho Nacional de Desenvolvimento Científico e Tecnológico (CNPq/MCTI), Biodiversity Research 
Program, Brazilian Rainforest Network (PPBio-MA, Research Grant 457483/2012-1). N. C. Fonsêca received a Master's scholarship from CAPES through the Forest Sciences MSc Program at UFRPE; A. C. B. Lins e Silva receives a grant from PET/Ministry of Education. We thank the administration of the Dois Irmãos State Park for research permit; E. Albuquerque and R. Berger for comments on earlier versions of the manuscript; M.A. Chagas for field assistance; and the Plant Ecology Laboratory (LEVE) for all assistance.

\section{RESUMEN}

¿Pueden los árboles caídos mejorar la estimación de la biomasa aérea? Una propuesta para el bosque atlántico brasileño. Introducción: La estimación de la biomasa aérea (AGB) en los bosques protegidos es un desafío, debido a los altos costos y las restricciones legales para las evaluaciones directas, y también a una estimación con frecuencia débil proporcionada por las ecuaciones generales de AGB. Objetivo: Proponemos un nuevo enfoque que utiliza los árboles muertos caídos (DFT) para mejorar la estimación de AGB. Nuestro objetivo es responder si el ajuste de modelos alométricos basados en DFT proporciona una ecuación local adecuada para la estimación de AGB o ayuda a validar las ecuaciones alométricas pantropicales o regionales existentes. Métodos: El estudio se realizó en el Parque Estatal Dois Irmãos (PEDI), Pernambuco, Nordeste de Brasil. En el espacio de 4000 m, utilizando la técnica de intersección de líneas, se tomaron muestras de 37 árboles muertos recientemente que van desde 7.6 a $92.3 \mathrm{~cm}$ de diámetro y 8.6 a $29.4 \mathrm{~m}$ de altura. Se ajustaron nueve modelos y se comparó la mejor ecuación (local) con las ecuaciones regionales y pantropicales. Resultados: Una ecuación $\left(\mathrm{AGB}_{\mathrm{kg}}=1.5292 * \mathrm{DBH}^{2.0601} * \mathrm{TH}^{-0.2187}\right)$ determinó estimaciones de biomasa que no diferían de los valores observados $(\mathrm{p}>0.05)$. A diferencia de las otras, esta ecuación sobreestimó AGB en solo $2.8 \%$ y, junto con otros parámetros de análisis $\left(\mathrm{R}^{2}{ }_{\text {adj }} \mathrm{y}\right.$ Syx $\left.\%\right)$, presentó el mejor rendimiento general. Analizando el rendimiento de la ecuación local versus las ecuaciones disponibles para estimar AGB, encontramos que solo las ecuaciones locales y pantropicales de Pearson et al. (2005) estimaron valores que no fueron significativamente diferentes de los valores observados. Sin embargo, la ecuación local es más apropiada para la estimación local de AGB, ya que tiene el RSME y CV más bajos. Conclusiones: Con base en el enfoque propuesto, pudimos proponer una ecuación local para la estimación de AGB basada en árboles caídos. La estimación basada en DFT es eficiente en términos de tiempo y costo, evita la tala de árboles en bosques protegidos y ayuda a guiar la elección de una ecuación adecuada para las demandas de AGB forestales.

Palabras clave: bosque tropical; ecuaciones alométricas; árboles caídos muertos; volumen del fuste; diámetro; altura; densidad de madera.

\section{REFERENCES}

Alvarez, E., Duque, A., Saldarriaga, J., Cabrera, K., Las Salas, G., Del Valle, I., ... Rodríguez, L. (2012). Tree above-ground biomass allometries for carbon stocks estimation in the natural forests of Colombia. Forest Ecology and Management, 267, 297-308.

Alves, D., Soares, J.V., Amaral, S., Mello, E., Almeida, S., Silva, O.F., \& Silveira, A. (1997). Biomass of primary and secondary vegetation in Rondônia, Western Brazilian Amazon. Global Change Biology, 3, 451-461.

Alves, L.F., Scaranello, M.A., Camargo, P.B., Santos, F.A.M., Joly, A.C., \& Martinelli, L.A. (2010). Forest structure and live aboveground biomass variation along an elevational gradient of tropical Atlantic moist forest. Forest Ecology and Management, 260, 679-691.

Anderson-Teixeira, K.J., Wang, M.M.H., Garvey, J.C.M.C., \& Bauer, D.L. (2016). Carbon dynamics of mature and regrowth tropical forests derived from a pantropical data base (TropForC-db). Global Change Biology, 22, 1690-1709.

ABNT. (2003). NBR 11941. Madeira: determinação da densidade básica. Retrieved from https://docslide. com.br/documents/nbr-11941-densidade-basica-damadeira.html

Baker, T.R., Honorio, C.E.N., Phillips, O.L., Martin, J., Van der Heijden, G.M.F., Garcia, M., \& Silva, E.J. (2007). Low stocks of coarse woody debris in a Southwest Amazonian forest. Oecologia, 152, 495-504.

Barbosa, R.I., Ramírez-Narváez, P.N., Fearnside, P.M., Villacorta, C.D.A., \& Carvalho, L.C.S. (2019). Allometric models to estimate tree height in Northern Amazonian ecotone forests. Acta Amazonica, 49, 81-90.

Benedetti, M.M., Curi, N., Sparovek, G., Carvalho Filho, A., \& Silva, S.H.G. (2011). Updated Brazilian's Georeferenced Soil Database - An Improvement for International Scientific Information Exchanging. In E. Burcu Oskaraova Gungor (Eds.), Updated Brazilian's Georeferenced Soil Database - An Improvement for International Scientific Information Exchanging ( $1^{\text {st }}$ ed., pp. 309-332). Brazil: InTech Open Access Publisher. 
Box, G., \& Cox, D.R. (1964). An analysis of transformations. Journal of the Royal Statistical Society, 26, 211-252.

Brown, S., Gillespie, A.J.R., \& Lugo, A.E. (1989). Biomass estimation methods for tropical forests with applications to forest inventory data. Forest Science, $35,881-902$.

Burger, D.M., \& Delitti, W.B.C. (1999). Fitomassa epigéa da mata ciliar do rio Mogi-Guaçu, Itapira-SP. Brazilian Journal of Botany, 22, 429-435.

Burger, D.M., \& Delitti, W.B.C. (2008). Allometric models for estimating the phytomass of a secondary Atlantic Forest area of Southeastern Brazil. Biota Neotropica, 8, 131-136.

Chambers, J.Q., Higuchi, N., Schimel, J.P., Ferreira, L.V., \& Melack, J.M. (2000). Decomposition and carbon cycling of dead trees in tropical forests of the central Amazon. Oecologia, 122, 380-388.

Chao, K., Phillips, O.L., \& Baker, T.R. (2008). Wood density and stocks of coarse woody debris in a Northwestern Amazonian landscape. Canadian Journal of Forest Research, 38, 795-825.

Chao, K.J., Phillips, O.L., Baker, T.R., Peacock, J., LopezGonzalez, G., Vasquez Martinez, R., Monteagudo, A., \& Torres-Lezama, A. (2009). After trees die: quantities and determinants of necromass across Amazonia. Biogeosciences, 6, 1615-1626.

Chave, J., Andalo, C., Brown, C., Cairns, M.A., Chambers, J.Q., Eamus, D., Fõlster, H., ... Yamakura, T. (2005). Tree allometry and improved estimation of carbon stocks and balance in tropical forests. Oecologia, 145, 87-99.

Chave, J., Méchain, M.R., Búrquez, A., Chidumayo, E., Colgan, M.S., ... Duque, A. (2014). Improved allometric models to estimate the aboveground biomass of tropical trees. Global Change Biology, 20, 3177-3190.

Chave, J., Coomes, D., Jansen, S., Lewis, S.L., Swenson, N.G., \& Zanne, A.E. (2009). Towards a worldwide wood economics spectrum. Ecology Letters, 12, 351-366.

Cunha, G.M., Gama-Rodrigues, A.C., Gama-Rodrigues, E.F., \& Velloso, A.C.X. (2009). Biomassa e Estoque de Carbono e Nutrientes em Florestas Montanas de Mata Atlântica na região Norte do Estado do Rio de Janeiro. Revista Brasileira de Ciências do Solo, 33, 1175-1185.

DataFit (2020). Science and engineering tool that simplifies the tasks of data plotting (Version 8.0.32, Oakdale Engineering, Oakdale, PA, EUA. Retrieved from https://datafit.software.informer.com/8.0
Deus, K.H.P., Bonete, I.P., Figueiredo, A.F.O., Dias, N.A., \& Bonete, I.P. (2018). Woody necromass stock in mixed ombrophilous forest using different sampling methods. Revista Caatinga, 31, 674-680.

Djomo, A.E., \& Chimi, C.D. (2017). Tree allometric equations for estimation of above, below and total biomass in a tropical moist forest: Case study with application to remote sensing. Forest Ecology and Management, 391, 184-193.

Fayolle, A., Ngomanda, A., Mbasi, M., Barbier, N., Bocko, Y., Boyemba, F., ... Mofack, G.I.I. (2018). A regional allometry for the Congo basin forests based on the largest ever destructive sampling. Forest Ecology and Management, 430, 228-240.

Finger, C.A.G. (1992). Fundamentos de biometria florestal. Santa Maria, Brasil: CEPEF/ FATEC/UFSM.

Fonsêca, N.C., Meunier, I.M.J., \& Silva, A.C.B.L. (2019). Evaluation of the Plant Necromass Component: Methodological Approaches and Estimates in Atlantic Forest, Northeast Brazil. Floresta e Ambiente, $26,1-10$.

Husch, B. (1963). Forest mensuration and statistics. New York, United States of America: The Ronald Press Company.

Huy, B., Poudel, K.P., \& Temesgen, H. (2016). Aboveground biomass equations for evergreen broadleaf forests in South Central Coastal ecoregion of Viet Nam: Selection of eco-regional or pantropical models. Forest Ecology and Management, 376, 276-283.

Keller, M., Palace, M., Asner, G.P., Pereira, R., \& Silva, J.N.M. (2004). Coarse woody debris in undisturbed and logged forests in the eastern Brazilian Amazon. Global Change Biology, 10, 784-795. DOI: 10.1111/j.1529-8817.2003.00770.x

Ketterings, Q.M., Coe, R., Noordwijk, M.V., Ambagau, Y., $\&$ Palm, C.A. (2001). Reducing uncertainty in the use of allometric biomass equations for predicting aboveground tree biomass in mixed secondary forests. Forest Ecology and Management, 146, 199-209.

Lau, A., Bentley, L.B., Martius, C., Shenkin, A., Bartholomeus, H., Raumonen, P., ... Herold, M. (2018). Quantifying branch architecture of tropical trees using terrestrial LiDAR and 3D modelling. Trees, $32,1219-1231$.

Lôbo, D., Leão, T., Melo, F.P.L., Santos, A.M.M., \& Tabarelli, M. (2011) Forest fragmentation drives Atlantic forest of Northeastern Brazil to biotic homogenization. Diversity and Distributions, 17, 287-296.

Magnusson, W.E., Lima, A.P., Luizão, R., Luizão, F., Costa, F.R.C., Castilho, C.V., \& Kinupp, V.F. (2005). RAPELD: a modification of the Gentry method for biodiversity surveys in long-term ecological research sites. Biota Neotropica, 5, 1-6. 
Meyer, W.H. (1944). A method of volume diameter ratios for board foot volume tables. Journal of Forestry, $42,185-94$.

Mittermeier, R.A., Turner, W.R., Larsen, F.W., Brooks, T.M., \& Gascon, C. (2011). Global Biodiversity Conservation: The Critical Role of Hotspots. In F.E. Zachos, \& J.C. Habel (Eds.), Biodiversity Hotspots: Distribution and Protection of Conservation Priority Areas (pp. 3-22). Germany: Springer-Verlag.

Monteiro, H., Lima, A.L.A., Silva, A.C.B.L.E., Silva, M.A.M., \& Rodal, M.J.N. (2017). Influence of functional traits on the demographic rates of 47 arboreal species in a tropical forest in Northeastern Brazil. Journal of Environmental Analysis and Progress, 2, 23-35.

Moreira, A.B., Gregoire, T.G., \& Do Couto, H.T.Z. (2019). Estimation of the volume, biomass and carbon content of coarse woody debris within two forest types in the State of São Paulo, Brazil. Forestry: An International Journal of Forest Research, 92, 278-286.

Näslund, M. (1940). Funktioner och tabeller för kubering av stående träd. Tall, gran och björk i norra Sverige. Medd. Stat. Skogsförsöksanst, 32, 87-142.

Ngomanda, A., Obiang, N.L.E., Lebamba, J., Mavouroulou, Q.M., Gomat, H., Mankou, G.S., ... Picard, N. (2014). Site-specific versus pantropical allometric equations: Which option to estimate the biomass of a moist central African forest? Forest Ecology and Management, 312, 1-9.

Nogueira Junior, L.R., Engel, V.L., Parrotta, J.A., Melo, A.C.G., \& Ré, D.S. (2014). Allometric equations for estimating tree biomass in restored mixed-species Atlantic Forest stands. Biota Neotropica, 14, 1-9.

Palace, M., Keller, M., \& Silva, H. (2008). Necromass production: studies in undisturbed and logged amazon forests. Ecological Applications, 18, 873-884.

Paula, M.D., Costa, C.P.A., \& Tabarelli, M. (2011). Carbon storage in a fragmented landscape of Atlantic forest: the role played by edge-affected habitats and emergent trees. Tropical Conservation Science, 4, 349-358.

Pearson, T. S., Walker, S., \& Brown, W.S. 2005. Sourcebook for Land Use, Land-Use Change and Forestry Project. Washington, D.C., United States of America: World Bank.

R Core Team. (2020). R: A language and environment for statistical computing. R Foundation for Statistical Computing, Vienna, Austria. Retrieved from https:// www.r-project.org
Rezende, A.V., Vale, A.T., Sanquetta, C.R., Filho, A.F., \& Felfili, J.M. (2006). Comparação de modelos matemáticos para estimativa do volume, biomassa e estoque de carbono da vegetação lenhosa de um cerrado sensu stricto em Brasília, DF. Scientia Florestalis, $71,65-76$.

Ribeiro, M.C., Metzger, J.P., Martensen, A.C., Ponzoni, F.J., \& Hirota, M.M. (2009). The Brazilian Atlantic Forest: How much if left, and how is the remaining forest distributed? Implications for conservation. Biological Conservation, 142, 1141-1153.

Saatchi, S.S., Harris, N.L., Brown, S., Lefsky, M., Mitchard, E.T.A., Salas, W., ... Morel, A. (2011). Benchmark map of forest carbon stocks in tropical regions across three continents. Proceedings of the National Academy of Sciences of the United States of America, 108, 9899-9904.

Sanquetta, C.R., Corte, A.P.D., Pinto, C., \& Melo, L.A.N (2014). Biomass and carbon in non-woody vegetation, dead wood and litter in Iguaçu National Park. Revista Floresta, 44, 185-194.

Santos, B.A., Peres, C.A., Oliveira, M.A., Grillo, A., Alves-Costa, C.P., \& Tabarelli, M. (2008). Drastic erosion in functional attributes of tree assemblages in Atlantic forest fragments of Northeastern Brazil. Biological Conservation, 141, 249-260.

Schumacher, F.X. (1942). Forest mensuration. New York, United States of America: McGraw-Hill.

Schumacher, F.X., \& Hall, F.S. (1933). Logarithmic expression of timber-tree volume. Journal of Agricultural Research, 47, 719 -734.

Silva, L.F.S.G., Castilho, C.V.C., Cavalcante, C.O., Pimentel, T.P., Fearnside, P.M., \& Barbosa, R.I. (2016). Production and stock of coarse woody debris across a hydro-edaphic gradient of oligotrophic forests in the Northern Brazilian Amazon. Forest Ecology and Management, 364, 1-9.

Spurr, S.H. (1952). Forest inventory. New York, United States of America: The Ronald Press Company.

Stas, S.M., Rutishauser, E., Chave, J., Anten, N.P.R., \& Laumonier, Y. (2017). Estimating the aboveground biomass in an old secondary forest on limestone in the Moluccas, Indonesia: Comparing locally developed versus existing allometric models. Forest Ecology and Management, 389, 27-34.

Tiepolo, G., Calmon, M., \& Ferretti, A.R. (2002). Measuring and monitoring carbon stocks at the Guaraqueçaba climate action project, Paraná, Brazil. In: International Symposium on Forest Carbon Sequestration and Monitoring (Proceedings, pp. 98-115, 
Extension Series, 153). Taipei: Taiwan Forestry Research Institute.

Vieira, S.A., Alves, L.F., Aidar, M.P.M., Araújo, L.S., Baker, T., Batista, J.L.F., ... Trumbore, S.E. (2008). Estimation of biomass and carbon stocks: the case of the Atlantic Forest. Biota Neotropica, 8, 21-29.

Villanova, P.H., Torres, C.M.M.E., Jacovine, L.A.G., Soares, C.P.B., da Silva, L.F., Schettini, B.L.S., ... Zanuncio, J.C. (2019). Necromass Carbon Stock in a Secondary Atlantic Forest Fragment in Brazil. Forests, 10, 833-843.

Warren, W.G., \& Olsen, P.F. (1964). A line intersect technique for assessing logging waste. Forest Science, $10,267-276$.

Zanne, A.E., Lopez-Gonzalez, G., Coomes, D.A., Ilic, J., Jansen, S., Lewis, S.L., ... Chave, J. (2009). Data from: Towards a worldwide wood economics spectrum. Dryad, Dataset, 2, 1-2. DOI: 10.1111/j.1461-0248.2009.01285.x

See Digital Appendix at: / Ver Apéndice digital en:

revistas.ucr.ac.cr 